\title{
Endodontic Treatment of Surgical Repositioned Traumatically-Intruded Maxillary Incisors Permanent Teeth
}

\author{
Buddiwati Punta ${ }^{1}$, Silvy D. Manulang ${ }^{2}$ \\ ${ }^{1}$ Endodontist, Department of Conservative Dentistry, Siloam Hospitals Lippo Village, Tangerang \\ ${ }^{2}$ Oral Surgeon, Department of Oral Sugery, Siloam Hospitals Lippo Village, Tangerang \\ Correspondence e-mail to: buddiwati@yahoo.co.id
}

\begin{abstract}
This report presents the case of a 10-year-old girl who was referred to the Siloam Hospital Lippo Village (SLVH) Dental Clinic 6 days after sustaining a severe traumatism that led to intrusion of the maxillary central and lateral incisors. The intruded teeth were repositioned by using surgical reposition and splinted. Endodontic treatment was performed 3 weeks after repositioning. The root canals were rinsed with $2.5 \% \mathrm{NaOCl}$, then calcium hydroxide dressing was placed. Splint was removed after 3 months. Definitive root canal fillings were accomplished 6 months later. The result implied that endodontic treatment until 9 months showed no periodontal complication, but 2 months later the teeth were slightly discolored. Further follow up should be made yearly for at least 5 years, because luxation injuries frequently do not show problems initially. In this case, surgical repositioning combined with endodontic treatment is a viable alternative treatment for severe traumatic intrusion in mature permanent teeth.
\end{abstract}

\begin{abstract}
ABSTRAK
Perawatan endodontik setelah perwatan bedah reposisi gigi insisif permanen intrusi pascatrauma. Laporan ini menggambarkan sebuah kasus trauma gigi berat pada seorang anak perempuan berusia 10 tahun yang mengakibatkan intrusi insisif sentral dan lateral rahang atas, yang terjadi 6 hari sebelum ditangani di Klinik Gigi Rumah Sakit Siloam Lippo Village (SLVH). Reposisi gigi secara bedah dan penggunaan splin dilakukan untuk merawat gigi intrusi. Perawatan endodontik dilakukan 3 minggu setelah reposisi. Saluran akar diirigasi dengan larutan $\mathrm{NaOCl}$ 2,5\% dan ditumpat sementara menggunakan kalsium hidroksida. Splin dilepas setelah 3 bulan. Perawatan saluran akar definitif dilakukan 6 bulan kemudian. Evaluasi perawatan endodontik 9 bulan setelah trauma tidak menunjukkan komplikasi, namun terjadi diskolorasi gigi 2 bulan berikutnya. Kontrol lanjutan dilakukan setiap tahun selama 5 tahun, karena biasanya trauma luksasi belum menunjukkan masalah pada di tahun-tahun pertama. Kombinasi reposisi bedah dengan perawatan endodontik merupakan perawatan yang diperlukan untuk menangai kasus intrusi gigi pascatrauma pada gigi yang sudah tumbuh sempurna.
\end{abstract}

Key words: endodontic treatment, intrusive luxation, surgical repositioning

\section{PENDAHULUAN}

Trauma gigi khususnya intrusi yang mengenai gigi permanen anterior baik pada anak-anak maupun orang dewasa sering kali menjadi masalah yang sulit bagi para dokter gigi dalam praktek sehari-hari. Andreasen, menyatakan bahwa Intrusi merupakan salah satu trauma luksasi gigi yang paling sulit dan jarang terjadi, hanya sekitar $0,3-1,9 \%$ dari seluruh injuri traumatik pada gigi permanen. ${ }^{1}$ Jarangnya kasus intrusi mengakibatkan terbatasnya penelitian-penelitian yang mendukung metode perawatan yang tepat. Sampai saat ini perawatan yang optimal dari luksasi intrusi selalu menjadi kontroversial, dan keberhasilannya masih diperdebatkan karena kompleksnya komplikasi yang terjadi paska perawatan. ${ }^{2,3}$ Bila gigi intrusi tidak segera dirawat, dapat menimbulkan dampak negatif bagi anak, sehingga orang tua selalu berusaha untuk tetap mempertahankan gigi tersebut agar tidak dilakukan pencabutan. Hal ini menjadi tantangan kita sebagai dokter gigi untuk dapat melakukan perawatan yang optimal.

Luksasi intrusi adalah pergeseran sebagian atau seluruh permukaan mahkota gigi ke soketnya dalam arah aksial (arah apeks), bahkan mahkota gigi 
benar-benar terbenam sampai tidak terlihat sama sekali, karena tertanam seluruhnya ke dalam tulang alveolar sehingga mobilitas gigi menurun menyerupai ankilosis. ${ }^{4,5}$ Intrusi yang berat dapat menyebabkan kerusakan pada jaringan pulpa, jaringan periodontium, neurovaskular, dan keadaaan ini mengakibatkan komplikasi paska perawatan seperti nekrosis pulpa, resorbsi akar eksterna, resorbsi inflamasi, resorbsi pengganti, kalsifikasi pulpa, dan hilangnya tulang marginal. ${ }^{4-6}$

Perawatan kasus intrusi bervariasi bergantung pada perkembangan akar gigi dan beratnya intrusi yang terjadi. ${ }^{2}$ Ada 3 cara perawatan intrusi yaitu reposisi pasif, reposisi secara bedah dan reposisi dengan ortodontik yang disebut sebagai reposisi aktif. ${ }^{3-5}$ Beberapa penelitian menyatakan bahwa intrusi mencapai $3 \mathrm{~mm}$ masih mempunyai prognosis yang baik, tetapi $>6 \mathrm{~mm}$ memiliki prognosis yang buruk.

Beberapa penelitan menyatakan bahwa gigi dengan apeks tertutup yang mengalami intrusi, 100\% akan terjadi nekrosis pulpa, sedangkan gigi dengan apeks terbuka hanya $62,5 \% .^{7}$ Oleh karena itu bila gigi menjadi nekrotik akibat intrusi perawatan endodontik menjadi pilihan, dan perawatannya sangat bervariasi bergantung pada pertumbuhan apeks gigi apakah sudah terbentuk sempurna atau masih terbuka. ${ }^{8}$ Bila terjadi nekrosis dan apeks sudah tertutup, maka perawatan endodontik harus dimulai 2-3 minggu setelah trauma.?

Keuntungan reposisi secara bedah yaitu dapat memberikan akses ke dalam saluran akar dengan cepat, selain mencegah kemungkinan terjadinya resorbsi inflamasi atau resorpsi pengganti (ankilosis). ${ }^{9}$ Perawatan kasus intrusi selalu merupakan tantangan bagi para dokter gigi dan adanya pendekatan multidisiplin seperti dengan bedah mulut, ortodontis, endodontis sangatlah penting agar tercapai hasil yang memuaskan.

Dalam makalah ini akan dilaporkan satu kasus luksasi intrusi parah, pada gigi permanen insisif sentral atas kanan dan insisif lateral atas kiri akibat kecelakaan jatuh tertabrak motor, dengan reposisi secara bedah dikombinasi dengan perawatan endodontik konvensional.

\section{LAPORAN KASUS}

Seorang anak wanita berumur 11 tahun dirujuk ke bagian gawat darurat Rumah Sakit Siloam LippoVillage (SHLV), dari Rumah Sakit Siloam Jambi, setelah 2 hari sebelumnya mengalami kecelakaan lalu lintas jatuh tertabrak motor. Pasien mendapatkan imunisasi tetanus sebelum mendapatkan perawatan di poli gigi. Pemeriksaan ekstraoral memperlihatkan bekas jahitan daerah dagu kanan dan laserasi di bawah bibir, tidak ada asimetris wajah. Pemeriksaan intraoral terlihat gigi 22 intrusi parah sampai mahkota tidak terlihat, gigi 21 sedikit ekstrusi, goyang, dan tidak fraktur, gigi 11 intrusi dan luksasi ke arah labial disertai kerusakan tulang alveolar, gigi 12 goyang derajat 1 dan tidak fraktur. Palpasi jaringan adanya fraktur alveolar bagian labial dan palatal, laserasi jaringan lunak disertai perdarahan, dan pembengkakan (Gambar 1). Gambaran radiografis memperlihatan akar gigi 11, 22 intrusi kedalam tulang alveolar dengan sangat ekstrim, dan terlihat foramen apikal gigi 21, 12 sudah terbentuk sempurna tidak terlihat kelainan periapikal maupun fraktur akar (Gambar 2).

Diagnosis adalah nekrosis pulpa akibat trauma intrusi pada gigi permanen insisif sentral atas kanan dan insisif lateral atas kiri. Rencana terapi dilakukan reposisi bedah dilanjutkan perawatan endodontik konvensional.

\section{Kunjungan 1}

Keadaan gigi geligi sebelum di reposisi, gigi 11 dan 22 terlihat intrusi sangat parah, dan akar sudah terbentuk sempurna maka rencana terapi dilakukan reposisi secara bedah. Reposisi bedah dengan anestesi lokal yang sudah tertunda selama 6 hari dilakukan pada gigi 11 dan 22. Reposisi dilakukan dengan menarik keluar secara hati-hati menggunakan tang dan dikembalikan ke posisi semula. Gigi 21 yang sedikit ekstrusi ditekan ke dalam soket sehingga posisi gigi kembali pada posisi yang normal (Gambar 3). Tulang alveolar yang fraktur di kembalikan ke posisinya, gingiva yang terbuka dijahit, dan untuk menstabilkan, gigi di etsa di fiksasi dengan splin resin komposit (Gambar 3). Stainlesteel arch wire selanjutnya digunakan karena splin resin komposit sulit bertahan. Pemberian antibiotik dan analgetik selama 7 hari, dan pasien diberitahu untuk tidak mengunyah makanan yang keras dan menjaga kebersihan rongga mulut. Pasien dikembalikan ke rawat inap untuk evaluasi pascaoperasi untuk kemudian pasien kembali ke Jambi.

\section{Kunjungan 2}

Setelah 17 hari, pasien datang kembali. Saat ini dipastikan gigi 11,21,22 menjadi nekrosis, lalu dilakukan perawatan saluran akar dengan pengukuran panjang kerja yang dikurangi sedikit dari panjang kerja sebenarnya, berturut-turut untuk masing-masing gigi. Gigi diirigasi dengan $\mathrm{NaOCl} 2,5 \%$, dikeringkan dengan kertas penghisap, lalu diisi pasta kalsium hidroksida $\left(\mathrm{Ca}(\mathrm{OH})_{2}\right)$ ditutup tumpatan sementara (Gambar 4).

\section{Kunjungan 3}

Pasien datang 2 bulan kemudian, splin metal terlepas sehingga wire masuk ke dalam gusi. Gusi terlihat bengkak, kemudian diputuskan untuk melepas splin metal dilepas dengan gigi masih goyang derajat dua. Pemeriksaan objektif memperlihatkan gigi 12 mengalami luksasi derajat dua. Tes vitalitas termal menggunakan dingin/panas menunjukkan hasil 
yang negatif. Pemasangan splin resin komposit dilakukan untuk stabilisasi gigi 12. Perawatan saluran akar dilanjutkan dengan melakukan pembukaan akses saluran akar gigi 12 yang dilanjutkan dengan pengukuran panjang kerja yang lebih panjang dari file awal untuk masing-masing gigi. Selanjutnya dilakukan perawatan saluran akar secara konvensional. Irigasi dilakukan dengan $\mathrm{NaOCl} 2,5 \%$, dikeringkan dengan kertas penghisap, lalu diisi dengan pasta $\mathrm{Ca}(\mathrm{OH})_{2}$ secara padat, ditutup dengan tumpatan sementara.

\section{Kunjungan 4}

Tiga bulan setelah kunjungan ke-3 pasien datang kontrol kembali, splin komposit dilepas, gigi masih goyang derajat satu. Perkusi gigi tidak ada rasa sakit, palpasi daerah labial tidak ada kelainan. Pasien dianjurkan kembali satu bulan lagi.

\section{Kunjungan 5}

Satu bulan setelah kunjungan ke-4, gigi geligi sudah tidak goyang. Tumpatan sementara dibuka dan dilakukan pembersihan saluran akar, mencoba kon utama berturut-turut pada gigi 11,12,21,22, di irigasi dengan $\mathrm{NaOCl} 2,5 \%$, dikeringkan kemudian dilakukan pengisian dengan pasta $\mathrm{Ca}(\mathrm{OH})_{2}$ yang baru dan ditutup tumpatan sementara .

\section{Kunjungan 6}

Sembilan bulan sejak kunjungan pertama, gigi 11, 12, 21, 22 stabil dan tidak goyang, perkusi negatif, dan tidak ada perubahan warna. Tumpatan sementara dibuka, dilakukan pembersihan saluran akar, dan diirigasi dengan $\mathrm{NaOCl} 2,5 \%$. Pengisian saluran akar dilakukan dengan gutta percha dan bahan pengisi saluran akar selanjutnya direstorasi dengan resin komposit

\section{Kunjungan 7}

Dua bulan setelah kunjungan ke-6 pasien datang, gigi 11, 21 mengalami perubahan warna kebiruan (Gambar 5). Gigi tidak goyang, perkusi negatif, dan tidak terdapat kelainan pada palpasi mukosa labial. Radiografis tidak memperlihatkan adanya resorpsi akar eksternal atau internal, dan tidak ada kelainan periapikal (Gambar 6). Untuk alasan estetis dianjurkan untuk dilakukan internal bleaching atau restorasi mahkota porselen, namun tetapi karena prognosis pascaintrusi memerlukan waktu cukup panjang, maka restorasi definitif ditunda sampai terlihat interpretasi hasil yang lebih baik.

Tabel 1. Derajat keparahan intrusi dan pertumbuhan $a_{k a r}^{8}$

\begin{tabular}{|c|c|c|}
\hline Derajat intrusi & Apeks terbuka & Apeks tertutup \\
\hline$\overline{\text { Ringan }(<3 \mathrm{~mm})}$ & $\mathrm{RP}$ & RP setelah 2-3minggu RO \\
\hline Sedang $(3-6 \mathrm{~mm})$ & RP & $\mathrm{RB}$ atau $\mathrm{RO}$ \\
\hline Berat $(>6 \mathrm{~mm})$ & RP & $\mathrm{RB}$ \\
\hline
\end{tabular}

Keterangan: $\mathrm{RP}=$ reposisi pasif, $\mathrm{RO}=$ reposisi ortodontik, $\mathrm{RB}=$ reposisi bedah

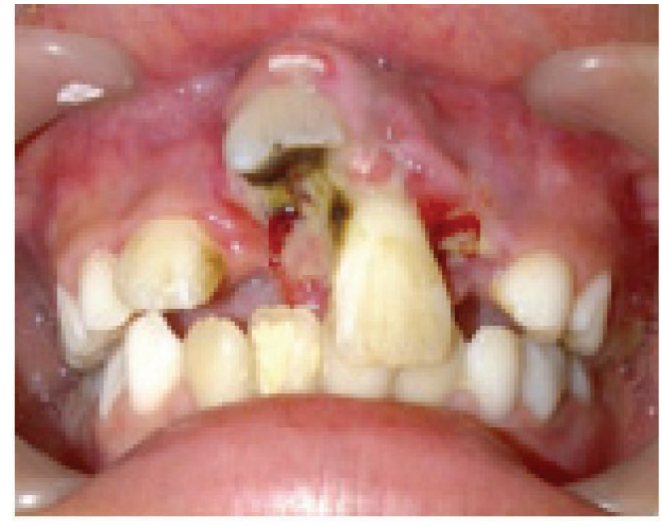

Gambar 1. Luksasi intrusi parah gigi 11 dan 22. Mahkota klinis gigi 22 tidak terlihat terbenam ke dalam soketnya. Gigi 21 sedikit ekstrusi. Laserasi jaringan lunak, fraktur tulang alveolar bagian palatal dan bukal, disertai perdarahan dan pembengkakan

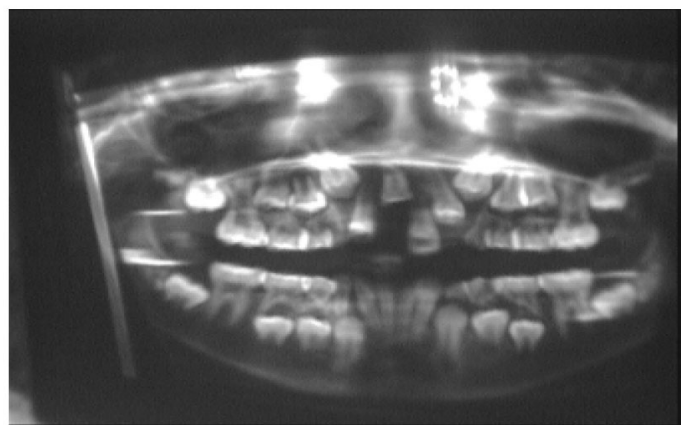

Gambar 2. Radiografis sebelum perawatan, gigi 11 dan 21 dengan intrusi parah, apeks terdesak kedalam tulang alveolar sampai seperti gigi yang sedang erupsi

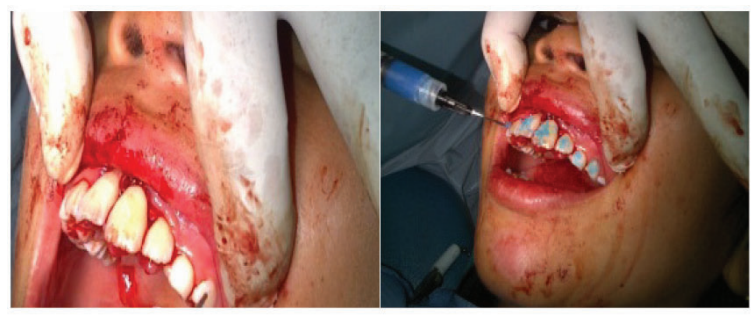

Gambar 3. Prosedur reposisi bedah yang telah dilakukan, dan prosedur etsa untuk pemasangan splin resin komposit
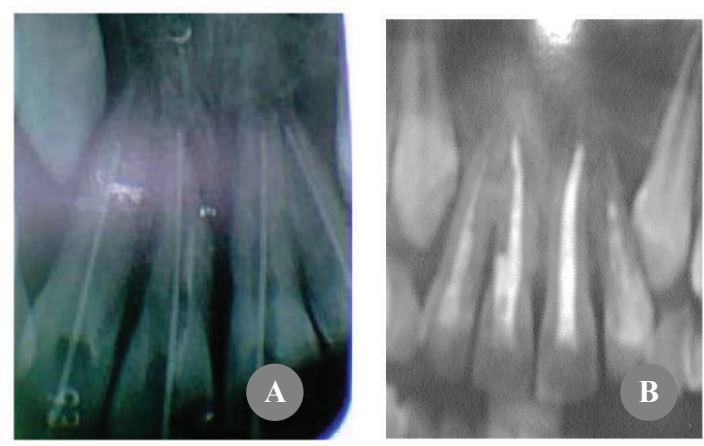

Gambar 4. Pengukuran file awal gigi 11, 21, 21, 22 A: terlihat tidak mencapai panjang kerja; B: intrakanal medikasi dengan pasta $\mathrm{Ca}(\mathrm{OH})_{2}$ 


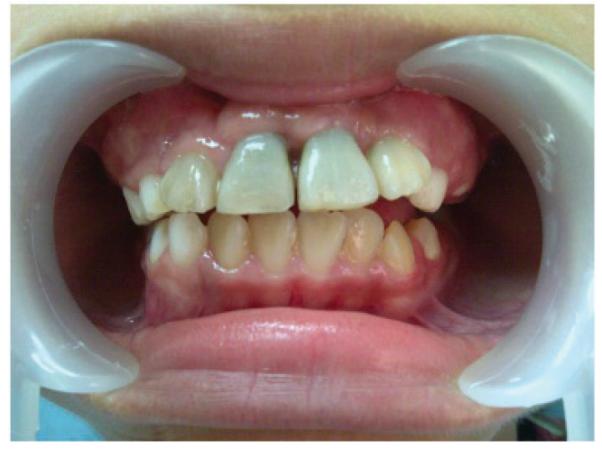

Gambar 5. Perubahan warna pada gigi 11, 21 satu tahun setelah perawatan

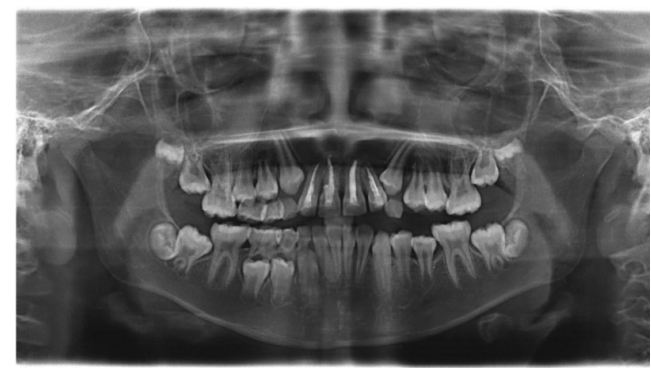

Gambar 6. Radiografis setelah 12 bulan masa perawatan tidak terlihat resorpsi akar (ankilosis), apeks telah terbentuk sempurna dan tidak terlihat kelainan periapikal. Gigi 24, 25 sudah erupsi dan 14, 15 belum erupsi

\section{PEMBAHASAN}

Luksasi intrusi khususnya pada gigi permanen merupakan kasus yang jarang terjadi, dan mempunyai komplikasi paska perawatan yang sangat bervariasi. Pemilihan terapi dan keberhasilan pascatrauma intrusi sampai saat ini, belum disepakati. Melalui penelitian dalam peiode 20 tahun (1983-2003) sebenarnya belum ada persetujuan secara umum untuk perawatan yang terbaik dari kasus intrusi pada gigi permanen. Strategi perawatan harus direncanakan derajat keparahan intrusi dan pertumbuhan akar. Menurut British Society of Pediatric Dentistry (BSPD) telah memberikan pedoman perawatan kasus intrusi, seperti terlihat dalam Tabel $1 .^{8}$

Dalam kasus ini, gigi 11 dan 22 mengalami intrusi yang sangat parah sehingga mahkota gigi 22 tidak terlihat sama sekali terbenam masuk ke soket lebih dari $6 \mathrm{~mm}$, dan gigi 11 intrusi dan luksasi ke labial. Perawatan pertama yang dilakukan dalam kasus ini adalah mengembalikan gigi tersebut ke posisi semula dengan reposisi secara bedah, seperti yang direkomendasikan sebelumnya, yaitu perawatan pilihan bagi gigi permanen yang intrusi adalah dengan reposisi bedah. ${ }^{9}$ Penelitian terdahulu menyatakan bahwa trauma tambahan yang dapat terjadi pada jaringan periodonsium pada saat reposisi bedah, dapat menambah kemungkinan komplikasi paska bedah, seperti resorpsi akar eksterna dan kehilangan dukungan tulang marginal..$^{10}$ Analisis pada 58 gigi permanen yang intrusi dan dilakukan reposisi bedah, menunjukkan bahwa semakin besar trauma saat reposisi, semakin besar kemungkinan terjadinya ankilosis. Terjadinya hal tersebut tidak mempengaruhi hilangnya dukungan tulang marginal, dengan demikian bahwa reposisi bedah tidak terbukti meningkatkan terjadinya resorpsi dukungan tulang marginal. ${ }^{11}$

Sebagian besar kasus yang telah dipubkasikan menyatakan bahwa pilihan perawatan untuk trauma instrusi pada gigi permanen dengan apeks tertutup lebih mengarah pada reposisi ortodonti daripada reposisi bedah. ${ }^{7}$ Reposisi ortodonti merupakan prosedur yang lebih biologis untuk gigi yang mengalami intrusi, terutama bila intrusi tidak melebihi $6 \mathrm{~mm}$.

Nekrosis pulpa dinyatakan akan terjadi pada $100 \%$ kasus luksasi intrusi yang parah pada gigi permanen dengan apeks tertutup. ${ }^{3,47}$ Gigi yang telah direposisi selama 2 sampai 3 minggu harus dilakukan perawatan saluran akar. Biasanya resorpsi akar akibat inflamasi akan terlihat secara radiografis 2 minggu setelah trauma. ${ }^{2}$ Perawatan trauma pada kasus ini sudah tertunda selama 17 hari, sehingga reposisi bedah lebih diutamakan dibandingkan reposisi ortodonti. Pertimbangan lainnya adalah dengan reposisi bedah, akses ke saluran akar lebih cepat dilaksanakan, sehingga perawatan endodonti dapat dilakukan sedini mungkin dengan harapan dapat menghentikan resorpsi inflamasi. ${ }^{9,10}$

Menurut Royal College of Surgeons of England (RCSE), untuk kasus intrusi kurang dari $3 \mathrm{~mm}$ pada gigi permanen dengan apeks masih terbuka, reposisi pasif (reerupsi) spontan merupakan pilihan perawatan, karena gigi masih mempunyai kemampuan untuk erupsi dan memperbaiki kerusakan jaringan pulpa dan periodontium dengan baik. ${ }^{12}$ Re-erupsi ini terjadi terutama bila gigi masih vital, dan jarang terjadi pada gigi yang nekrosis. ${ }^{7}$ Setelah 3 bulan pascatrauma gigi pada kasus ini, gigi 12 menjadi goyang derajat dua, dan nonvital, sehingga dilakukan perawatan saluran akar. Perawatan juga dilakukan pada gigi 12 yang tidak mengalami intrusi, tetapi kemungkinan mengalami benturan yang parah saat trauma, sehingga dengan berjalannya waktu gigi menjadi nekrosis.

Gigi intrusi yang sudah direposisi harus diberi splin, yang bertujuan menstabilkan gigi dan mencegah kerusakan lebih lanjut terhadap pulpa dan jaringan periodontium selama proses penyembuhan. ${ }^{8}$ Splin yang baik untuk kasus trauma adalah splin yang pasif bersifat fleksibel dan sementara, sehingga tidak memberi beban tambahan pada gigi. Dalam kasus ini setelah reposisi bedah, dilanjutkan dengan acid etch composite ligature wire splint. Dua bulan setelah pemasangan splin lepas, gigi masih agak goyang lalu dipasang kembali splin resin komposit dalam periode 3 bulan sampai gigi stabil dan 
tidak goyang. Lepasnya splin disebabkan gigi pegangan untuk menahan splin resin komposit hanya pada gigi molar satu dan kedua gigi geraham susu dengan jarak serviko-oklusal yang pendek sehingga tidak ada retensi, dan tidak kuat menahan mobilitas ke empat gigi anterior yang goyang. Splin yang baik adalah yang bersifat pasif, tetapi bila tidak ada retensi yang kuat maka splin akan terlepas. Pemilihan tipe splin bergantung pada kondisi gigi pegangan dan parahnya kegoyangan yang terjadi. Lamanya pemakaian splin bervariasi, bergantung parahnya trauma yang terjadi. Periode pemakaian splin sekitar 6-8 minggu setelah reposisi, tetapi idealnya splin harus dipakai sesingkat mungkin untuk memungkinkan jaringan periodonsium mengalami proses penyembuhan fisiologis. ${ }^{8}$

$\mathrm{Ca}(\mathrm{OH})_{2}$ yang dipakai pada setiap kunjungan sebagai obat saluran akar antar kunjungan mempunyai potensi menyembuhkan kelainan periapeks. ${ }^{13} \mathrm{Ca}(\mathrm{OH})_{2}$ dapat dipakai sebagai bahan pengisi sementara untuk beberapa bulan sampai saluran akar siap diisi secara tetap. Kemampuan biologis $\mathrm{Ca}(\mathrm{OH})_{2}$ dalam mendorong penyembuhan dan potensi pembentukan jaringan keras disebabkan oleh $\mathrm{pH}$ basa yang merubah lingkungan asam pada daerah resorpsi menjadi alkalis, sehingga dapat menghambat osteoklas dan terjadi aktivasi osteoblas yang menstimulasi pertumbuhan jaringan dan terjadinya deposisi jaringan keras. ${ }^{13}$

Dalam kasus ini, 2 bulan setelah dilakukan pengisian saluran akar, gigi berubah warna menjadi kebiruan hal ini merupakan salah satu komplikasi pascaperawatan gigi yang mengalami trauma. Gigi yang mengalami trauma terutama lukasi intrusi yang parah pada umumnya akan terjadi perdarahan intrapulpa akibat putusnya pembuluh darah di mahkota gigi dan lisisnya eritrosit. Keadaan ini menyebabkan dilepasnya produk disintegrasi darah seperti besi sulfida masuk ke dalam tubulus dentin sehingga menyebabkan perubahan warna gigi yang makin lama makin meningkat. Radiografis setelah 12 bulan perawatan, tidak menunjukkan adanya resorpsi inflamasi ataupun resorpsi pengganti (ankilosis). Untuk memperoleh interpretasi pascaperawatan yang lebih baik dibutuhkan kontrol selanjutnya setiap tahun, selama periode lima tahun.

\section{SIMPULAN}

Strategi untuk perawatan kasus intrusi, harus direncanakan sesuai dengan tingkat keparahan cedera dan pertumbuhan akar. Beberapa perawatan klinis untuk kasus ini antara lain dengan reposisi pasif, reposisi bedah, dan reposisi aktif dengan bantuan alat ortodonti. Perlu diingat, bahwa pendekatan multidisiplin ilmu yang terkait seperti dengan ilmu bedah mulut, ortodonti, dan endodonti harus dipertimbangkan, agar diperoleh hasil perawatan yang baik dengan sedikit komplikasi yang terjadi. Penggunaan pasta $\mathrm{Ca}(\mathrm{OH})_{2}$ sebagai pengisian sementara dapat menghentikan resorpsi inflamasi. Hasil dari laporan kasus ini menunjukkan bahwa gabungan reposisi bedah dengan perawatan endodonti merupakan perawatan pilihan yang cukup berhasil pada gigi permanen dengan luksasi intrusi yang parah.

\section{UCAPAN TERIMA KASIH}

Ucapan terima kasih kepada semua perawat gigi Rumah Sakit Siloam Lippo Karawaci Tangerang yang sudah membantu terlaksananya kasus ini.

\section{DAFTAR PUSTAKA}

1. Andreasen JO, Bakland LK, Matras R, Andreasen FM. Traumatic intrusion of pemanent teeth. Part 1. An epidemiological study of 216 intruded teeth. Dental Traumatol. 2006;22:83-9.

2. Andreasen FM, Andreasen JO. Luxation injuries. In: Textbook and color atlas of traumatic injuries to the teeth. 3rd ed. Copenhagen, Munksgaard. 1994. p. 315-78.

3. Torabinejad M, Walton RE. Management of traumatic dental injuries. In: Endodontics principles and practice. 4th ed. St. Louis, Missouri. 2009. p.163-84.

4. Bremann LH, Blanco L, Cohen S. Luxation injuries. In: A clinical guide to dental traumatology. 1st ed. St. Louis, Missouri; 2007. p.73-90.

5. Gutmann JL, Dumsha TC, Lovdahl PE. 2006. Problem-solving the diagnosis and management of accidental tooth trauma. In: Problem solving in endodontics. Prevention, identification, and management. 4th ed., St Louis, Missouri: Mosby; 2006. p.404-17.

6. Andreasen FM. Pulpal healing after luxation injuries and root fracture in the permanent dentition. Endod Dent Traumatol. 1989;5:111-31.

7. Diab M, elBadrawy HE. Intrusion injuries of primary incisors. Part I: Review and management. Quintessence Int. 2000;31:327-34.

8. Andreasen JO, Bakland LK, Andreasen FM. Traumatic intrusion of permanent teeth. Part 3. A clinical study of the effect of treatment variables such as treatment delay, method of repositioning, type of splint, length of splinting and antibiotics on 140 teeth. Dent Traumatol. 2006;22:99-111.

9. Al-Badri S, Kinirons M, Cole BO, Welbury RR. Factors affecting resorption in traumatically intruded permanent incisors in children. Dent Traumatol. 2002;18:73-6.

10. Caliskan MK. Surgical extrusion of a completely intruded permanent incisor. J Endod. 1998;24:3814. 
11. Ebeleseder KA, Santler G, Hulla H, Pertl C. Quehenberger F. An analysis of 58 traumatically intruded and surgically extruded permanent teeth. Endod Dent Traumatol. 2000;16:34-9.

12. Chaushu S, Shapira J, Heling I, Becker A. Emergency orthodontic treatment after the traumatic in- trusive luxation of maxillary incisors. Am J Orthod Dentofacial Orthop. 2004;126:162-72.

13. Murad C, Fariniuk LF, Fidel S, Fidel RA, Sassone LM. Bacterial leakage in root canals filled with calcium hydroxide paste associated with different vehicles. Braz Dent J. 2008;19:232-7. 